\title{
Drinking Water Analysis of Household Water and its Safe Storage Patterns by Linear Regression Technique in Mumbai, India
}

\author{
Swapnali D. Mahadik' and Anup Girdhar ${ }^{2}$ \\ Ph.D Research Scholar, TMV,Pune \\ ${ }^{1} M C A$, DES's NMITD, Mumbai, India (Affiliated to University to Mumbai), India \\ ${ }^{2}$ CEO, Founder, Sedulity solutions \& Technologies, Ph.D Guide, TMV, Pune, India
}

\begin{abstract}
This research paper deals with various safe storage patterns of water like Stainless steel, Earthen Pot (Matka), Copper vessels ,Plastic and direct use i.e. Tap water. In this storage patterns not all are hygienic and healthy for human body. In this research the linear regression technique is being used to classify the dataset. By implementing this technique it can be analyze that certainparameters fit to this specific model and fewparameters may not fit. The variation of the properties of water samples directly influence the primary productivity of the water.So the main motive of this research is to evaluate the contamination potentials of water to train the new data in future of different house water and storage patterns available in Mumbai, India.
\end{abstract}

\section{KEY WORDS: LINEAR REGRESSION, CONSUMPTION, CONTAMINATION, STAINLESS STEEL, COPPER.}

\section{INTRODUCTION}

Access to clean and safe water, good sanitation, and hygiene practices are necessary for a healthy population. Now a day's waterborne disease constitute a major health issues to the people due to poor water quality. The water must meet the required (chemical, biological and physical) quality standards at the point of supply to the users.[3] Consumption of contaminated water causes a high health risk especially to rural areas where common people can't afford the Water Purifiers /Filters. Through this it can be shows that from various storage patterns which storage can be healthy for human body even after 12 hours of storage of a water in a same vessel.

Biose Biotech Res Comm P-ISSN: 0974-6455 E-ISSN: 2321-4007

\section{crossef}

Identifiers and Pagination

Year: 2021 Vol: 14 No (5) Special Issue

Pages: $32-35$

This is an open access article under Creative

Commons License Attribn 4.0 Intl (CC-BY).

DOI: $h t t p: / / d x$.doi.org/10.21786/bbrc/14.5/6
Secure water may not necessarily be knowingly contaminated to pose a public health risk, but the handling from the source to many homes and the pattern of storage before water is finally consumed pose the main challenge for all including water consumers, water resource managers, and water storage facilities at communities and household levels. The trained data set is used to classify the parameters based on their values which can be easily map and predict the type of water either steel, copper, plastic, etc. in the future also.

Literature Review: Author Parker et al. with similar studies shows that household water quality is compromised by storage methods after collection, thus increasing the proportion of people drinking unsafe water. In a study by Raju et al.household water showed progressive contamination during storage, and in this study, almost three forth stored household water samples were contaminated with enteric bacteria. As stated by MegersaOlumanaDinka, different countries regulate drinking water differently depending on the quality of their water source. Stainless steel is a very popular metal for making water storage ware and drinkware. Pitchers, glasses and water bottle made of stainless steel are very

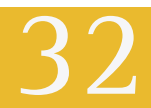


popular among people who are looking for a long-lasting and sustainable option.

The earth is rich in various vitamins and minerals. The earthen pots have the similar properties the earth consists of. Using earthen pot (matka) for water storage is not just a traditional or old fashioned alternative to the steel container, but it is a very well healthy alternative as well. This clay water pots are having amazing benefits like alkaline , Improves Metabolism, natural cooling , good for throat, prevention of sunstroke head stroke and may other things. According to Ayurveda it is stated that water stored in a copper vessel for a longer time has the ability to maintain all the three doshasof human body i.e. vata, kapha , pitta and it happens may be because of copper positively charge the water. Copper containers are one of the oldest types of vessels after clay vessels. Because of the positive antibacterial properties of copper, it is still generally used nowadays in many medical implements, kits, and water-storing containers worldwide.Apart from the antibacterial and alkalizing effects of copper on water, the copper ions present in water serve aexceptional role in the healthy functioning of the body. Human need copper as one of the important trace minerals which plays vital role in a number of functions all over.

Table 1.1 Safe Storage Water Samples and their Parametric Values

\begin{tabular}{|c|c|c|c|c|c|c|c|}
\hline $\begin{array}{l}\text { Parameters } \\
\text { Type }\end{array}$ & $\begin{array}{l}\text { Sr. } \\
\text { No. }\end{array}$ & Parameters & \begin{tabular}{|c||} 
Plastic \\
(polyethylene \\
terephthalate) \\
Sample1
\end{tabular} & $\begin{array}{l}\text { Stainless } \\
\text { Steel } \\
\text { Sample } 2\end{array}$ & $\begin{array}{c}\text { Mud Matka } \\
\text { (Earthen Pot) } \\
\text { Sample } 3\end{array}$ & $\begin{array}{l}\text { Copper } \\
\text { Vessels } \\
\text { Sample } 4\end{array}$ & $\begin{array}{c}\text { Tap } \\
\text { water } \\
\text { Sample } 5\end{array}$ \\
\hline $\begin{array}{l}\text { Essential } \\
\text { Parameters }\end{array}$ & $\begin{array}{l}1 \\
2 \\
3 \\
4 \\
5 \\
6\end{array}$ & $\begin{array}{c}\text { Color } \\
\text { Odur } \\
\text { Taste } \\
\text { PH } \\
\text { Turbidity } \\
\text { TDS }\end{array}$ & $\begin{array}{c}5 \\
\text { Agreeable } \\
\text { Agreeable } \\
7.8 \\
1 \\
52\end{array}$ & $\begin{array}{c}5 \\
\text { Agreeable } \\
\text { Agreeable } \\
7.7 \\
1 \\
45\end{array}$ & $\begin{array}{c}6 \\
\text { Agreeable } \\
\text { Agreeable } \\
7.7 \\
1 \\
46\end{array}$ & $\begin{array}{c}6 \\
\text { Agreeable } \\
\text { Agreeable } \\
7.8 \\
1 \\
45\end{array}$ & $\begin{array}{c}5 \\
\text { Agreeable } \\
\text { Agreeable } \\
7.9 \\
1 \\
58\end{array}$ \\
\hline $\begin{array}{l}\text { General } \\
\text { Parameter }\end{array}$ & $\begin{array}{l}12 \\
13 \\
14 \\
15 \\
16 \\
17 \\
18 \\
19\end{array}$ & $\begin{array}{c}\text { Aluminum (as Al), } \\
\text { mg/l, Max } \\
\text { Ammonia } \\
\text { (as total ammonia-N), } \\
\text { mg/l, Max } \\
\text { Calcium (as Ca), mg/l, Max } \\
\text { Chlorides } \\
\text { Copper (as Cu), } \\
\text { mg/l, Max } \\
\text { Iron (as Fe), mg/l,max } \\
\text { Free residual chlorine, mg/l, Min } \\
\text { Fluoride (as F) mg/l, Max } \\
\text { Manganese (as Mn), mg/l, Max } \\
\text { Mineral oil, mg/l, Max } \\
\text { Selenium (as Se), mg/l, Max } \\
\text { Silver (as Ag), mg/l, Max } \\
\text { Zinc (as Zn), mg/l, Max }\end{array}$ & $\begin{array}{c}0.2 \\
0.2 \\
1 \\
0.1 \\
0.1 \\
0.01 \\
0.1 \\
4\end{array}$ & $\begin{array}{c}0.3 \\
0.3 \\
1.2 \\
0.1 \\
0.1 \\
0.01 \\
0.1 \\
10\end{array}$ & $\begin{array}{c}0.2 \\
0.1 \\
1.1 \\
0.1 \\
0.1 \\
0.01 \\
0.1 \\
4\end{array}$ & $\begin{array}{c}0.3 \\
0.2 \\
1.2 \\
0.1 \\
0.2 \\
0.01 \\
0.1 \\
12\end{array}$ & $\begin{array}{c}0.5 \\
\\
80 \\
260 \\
0.9 \\
\\
0.3 \\
0.1 \\
1 \\
0.1 \\
0.3 \\
0.01 \\
0.1 \\
2\end{array}$ \\
\hline $\begin{array}{l}\text { Toxic } \\
\text { Substances }\end{array}$ & $\begin{array}{l}20 \\
21 \\
22 \\
23 \\
24\end{array}$ & $\begin{array}{c}\text { Cadmium (as Cd), mg/l, Max } \\
\text { Lead (as } \mathrm{Pb} \text { ), mg/l, Max } \\
\text { Mercury (as Hg), mg/l, Max } \\
\text { Total arsenic (as As), mg/l, Max } \\
\text { Total chromium (as Cr), mg/l, Max }\end{array}$ & $\begin{array}{c}0.004 \\
0 \\
0.005 \\
0.02 \\
0.01\end{array}$ & $\begin{array}{c}0.004 \\
0 \\
0.006 \\
0.02 \\
0.02\end{array}$ & $\begin{array}{c}0.002 \\
0 \\
0.006 \\
0.01 \\
0.02\end{array}$ & $\begin{array}{c}0.003 \\
0.01 \\
0.005 \\
0.02 \\
0.02\end{array}$ & $\begin{array}{c}0.002 \\
0 \\
0.006 \\
0.04 \\
0.02\end{array}$ \\
\hline
\end{tabular}

Sample Collection, Material and Methodology

Area of the Study: The study area is of Mumbai's urban and rural area. This study are was selected based on dense population and mix crowd. Water Sources: A total 20 samples of home storage water sample collection were collected from safe storage patterns. Here in table 1.1 only 5 samples are shown for reference. Which includes five types of storage patterns i.e. Plastic (polyethylene terephthalate), Stainless Steel, Mud Matka, Copper Vessels and Tap water which is shown in Table 1.1. From 
the time of sample collection and to the time of actual analysis, many physical and chemical reactions would change the quality of water sample and what changes can be possible because of storage patterns that is the main part of the study.

Therefore to analyze that water samples are preserved for 12 hours in safe storage and then only it is being tested to check variations for parametric values. Analysis is done on 24 different parameters as shown in table 1.1 parameters categories are of Essential, General and Toxic Substances as per the guidelines of Indian Standard Bureau and World Health Organization. Physical parameters like Temperature, Odour, Taste EtColour was agreeable in Process and Municipal water. The study was carried out for a period of March 2020 to June 2020. Parametric values are under the standard specifies the acceptable limits and the permissible limits in the absence of alternate source. In India it is recommended that the Drinking water quality standards has to be followed as per the Indian Standard Bureau and World Health Organization(WHO). However, if the value go beyond the limits indicated under "permissible limit in the absence of alternate source, the sources have to be rejected. In India, Central Pollution Control Board has identified requirements ofwater quality in the form of a chemical characteristics which is also called as primary water quality criteria. Further, Bureau of Indian Standards has recommended water quality parameters for different uses in the standard.

Figure 1.1: Linear Regression Implementation on Samples of Copper Vessels and Mud Matka

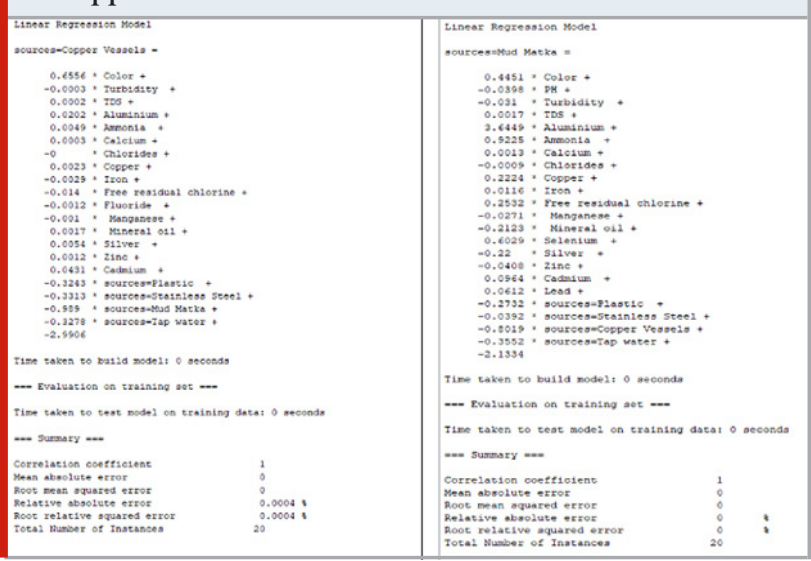

METHODOLOGY

Here Data were collected, and entered in Weka tool for implementing Linear Regression. The water samples were analyzed for the presence and correlation of 24 different parameters using the Standard Methods for the Examination. Such as pH, TDS, Iron, Turbidity, Copper, Iron, Mineral Oils, Manganese, Total arsenic etc.

\section{RESULTS AND DISCUSSION}

The main aim of linear regression is prediction, forecasting and error reduction. This technique is used to appropriate a predictive model to an observed data set of values of the responses.Here in this study quantitative data is analyzed using weka and implemented Linear regression on 20 samples with their 24 Essential,General and Toxic parameters for easy interpretation. Here in dataSet it Contains string variables so before implemeting regression it is being coverted first in numerical format for implementaion. This technique is implemented on a whole data set and divided into the diverse classes based on the storage patterns. Whenver with this prediction the new data set is going to be trained and it can be easily identified the storage pattern withoud knowing it. The results were reported seperately in terms of finding out the absolute error value.

Figure 1.1 shows the relative error value $0.0004 \%$ of Copper vessels and $0 \%$ value in other four types of storage vessels. But the classification shows predictive analysis for all the storage patterns which can be easily used to identify water is stored from which storage vessels.

Figure1.2: Linear Regression Implementation on Samples of Plastic and Stainless Steel

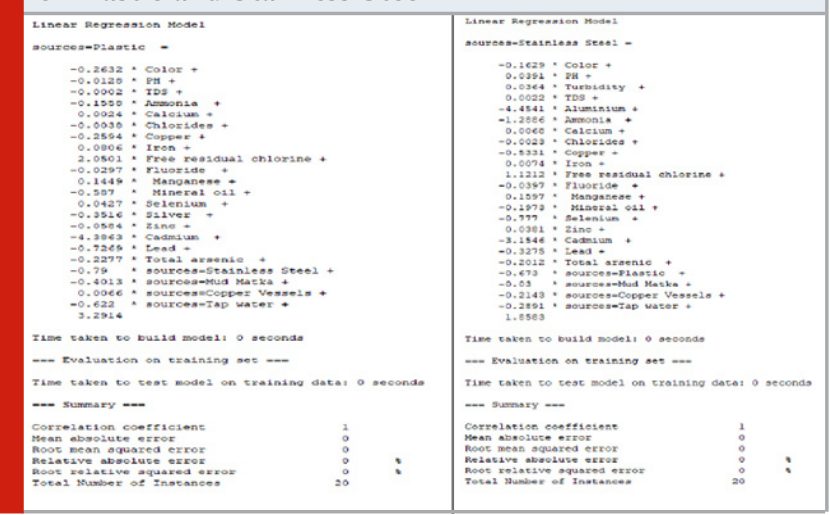

Figure 1.3: Linear Regression Implementation on Samples of Tap Water

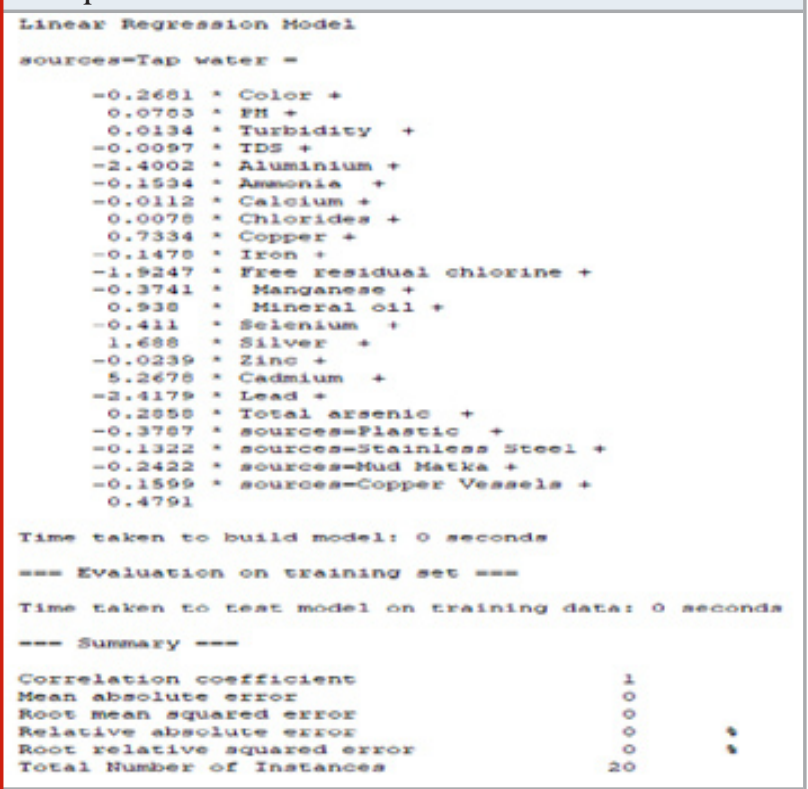


After developing this type of a model, if additional values of the explanatory variables are collected the fitted model can be easily used to make a prediction of the response. And that can be further analyzed for its quality using Machine learning algorithms.

\section{CONCLUSION}

The result obtained from the linear regression technique shows that after 12 hours of storage water in any particular type of vessel affect the quality of the water depends on the storage pattern but here the analysis does not show that much of variations in the sample of water. But copper vessels gives some change in parametric values which may affect the quality either in positive or negative way. So using this linear regression model, prediction classes made easier for more data set to identify the type of pattern by training them in the same model in future.

\section{REFERENCES}

Alexander Agensi, Julius Tibyangye , Andrew Tamale, EzeraAgwu, Christine Amongi , "Contamination Potentials of Household Water Handling and Storage Practices in KirundoSubcounty, Kisoro District, Uganda”, Hindawi Journal of Environmental and Public Health, Volume 2019 |Article ID 7932193,March 2019
Devangeeshukla*, KinjalBhadresha, Dr.N. K. Jain, Dr.H. A. Modi, "Physicochemical Analysis of Water from Various Sources and Their Comparative Studies", IOSR Journal of Environmental Science, Toxicology And Food Technology (IOSR-JESTFT)e-ISSN: 2319-2402,pISSN: 2319-2399.Volume 5, Issue 3 (Jul. -Aug. 2013), PP 89-92

Guidelines For Drinking water Quality , Fourth Edition ,Volume 1, WHO

Guidelines For Drinking water Quality , Third Edition ,Volume 1, WHO

https://doctor.ndtv.com/living-healthy/this-is-whyyou-should-use-a-clay-pot-to-store-drinking-water1712265

https://www.copperh2o.com/blogs/blog/the-ultimateguide-to-copper-vessels

https://www.copperutensilonline.com/blog/the-bestoption-for-drinking-water-copper-stainless-steel-glassor-plastic/

Hydrology and Water Resources Information System for India, http://117.252.14.242/rbis/india_information/ water\%20quality\%20standards.htm

Indian Standard Drinking Water- Specification (Second Revision), IS $10500: 2012$

MegersaOlumanaDinka, "Safe Drinking Water: Concepts, Benefits, Principles and Standards”, March 2018 